\title{
MEDICINOS DARBUOTOJŲ PRIEŠINIMASIS E. SVEIKATOS PASLAUGŲ PLÉTRAI
}

\author{
Gintautas Virketis ${ }^{1,2}$, Gintarẻ Kazlauskè ${ }^{3}$ \\ ${ }^{1}$ Klaipédos universitetas, ${ }^{2}$ Klaipédos universitetine ligonine,${ }^{3}$ Respublikinè Klaipédos ligonine
}

Raktažodžiai: e. sveikata, e. sveikatos paslaugos, priešinimasis.

\section{Santrauka}

Mokslinès literatūros apžvalga parodè, kad nors e. sveikata jau senokai taikoma ir tobulinama, jos plètrai trukdo medicinos darbuotojų priešinimasis. Sveikatos priežiūros specialistų priešinimosi sąvoka šiandien dar nèra apibrežta bendru sutarimu.

Tyrimo tikslas - išanalizuoti stacionarinès asmens sveikatos priežiūros įstaigos (ASPİ) specialistų požiūrị ị e. sveikatos paslaugų diegimo ir plètros problemas ir nustatyti priešinimąsi didinančius veiksnius.

Tyrimo metodika. Atliktas kiekybinis tyrimas - anketinè apklausa raštu. Anketa sudaryta atsižvelgiant ị kitų mokslininkų, nagrinëjusių e. sveikatos paslaugas, atliktus tyrimus. Tyrime dalyvavo 255 respondentai. Statistiniai duomenys apdoroti IBM SPSS 23.0 (Statistical Package for the Social Sciences) programiniu paketu. Rezultatai. Dauguma respondentų nurodè, kad jiems pakanka kompiuterinių žinių naudojantis e. sveikatos sistema, îstaigoje per žemas prioritetas teikiamas informacinių sistemų diegimui. Kompetencijos IT specialistams netrūksta, tačiau pildant medicininę informaciją e. sveikatoje, atsiranda tikimybė padaryti pildymo klaidų, nepakankamai sklandus e. sveikatos sistemos veikimas, dirbti e. sveikatos sistemoje reikia daugiau atidumo ir atsakomybės, nes naudojantis e. sveikata padidèjo darbo krūvis.

Išvada. Pagrindine e. sveikatos diegimo ir pletros problema - e. sveikatos sistemos sutrikimai ir gedimai, ilginantys paciento apžiūros laiką ir eiles. Dauguma gydytojų supranta ir teigiamai vertina plètojamos e. sveikatos sistemos naudą ir jos plačias galimybes. Tyrimo metu nustatyti veiksniai, didinantys priešinimąsi sékmingam e. sveikatos sistemos diegimui ir plètrai: nepakankamai sklandus e. sveikatos sistemos veikimas, e. sveikatos sistema reikalauja daugiau atidumo ir atsakomybės, nepakankamas skaičius personalo, gebančio naudotis informacinèmis sistemomis, pildant medicininę informaciją e. sveikatos sistemoje didelè pildymo klaidų tikimybè, kaupiami sveikatos ịrašai dubliuojami, naudojantis e. sveikata padidejo darbo krūvis.

\section{İvadas}

Sveikatos priežiūros sistemos kasdienèje veikloje, kurioje vis daugiau dominuoja elektroniniai procesai ir informacinès technologijos, elektroninès sveikatos (e. sveikata, eHealth arba e-health) terminas naudojamas dar neseniai. Sąvoka e. sveikata daugeliu atveju vartojama skirtingai, nes ji apima ne tik e. receptą [1], bet ir daugelị kitų paslaugų, kurios susieja mediciną su informacinèmis technologijomis, ịskaitant telesveikatą, telemediciną, mobiliają sveikatą (m. sveikata), elektroninius medicininius ar sveikatos įrašus (EMI/ESI), nuotolinę mediciną ir kitas technologijas [2].

Nors informacinių technologijų taikymo nauda sveikatos priežiūros paslaugoms gerinti įrodyta, jos gana plačiai ir jau senokai taikomos ir tobulinamos [3], tačiau mokslinès publikacijos ir atlikti tyrimai rodo, kad sveikatos priežiūros sektoriuje vis dar jaučiamas medicinos darbuotojų priešinimasis informacinių technologijų, kurios keičia įprastines veiklos procedūras asmens sveikatos priežiūros paslaugas teikiančiose įstaigose, diegimui ir plètrai [4-6]. Pati sveikatos priežiūros specialistų priešinimosi sąvoka nèra galutinai aptarta ir kol kas nèra bendro sutarimo [7]. Šiuo metu priešinimasis gali būti suprantamas plačiai, kaip bet koks veiksmas, kuri atlieka bet kuris asmuo (ar kolektyvas), aiškiai identifikuojantis save sveikatos priežiūros specialistu. Tai gali būti kaip atsakas valdžiai, dažniausiai prieštaraujant ginčytinoms, žalingoms ar neteisingoms taisyklèms, praktikai, politikai ar struktūroms. Praktiškai tai galètų būti bet kokie vieši veiksmai, eitynès, pasisèdèjimas ir pilietinis nepaklusnumas, taip pat „kasdienio pasipriešinimo“ formos, pvz., letai atliekamas darbas, ligos imitavimas ir kt. [8].

Lietuvoje atliktos mokslinès analizès ir ataskaitos rodo, kad sveikatos apsaugos sistemoje priešinimasis naujovèms yra reikšmingas, stiprus, įtakingas reiškinys, skatinantis priešintis dar nepradejjus svarstyti jų privalumų ir trūkumų 
$[9,10]$. Sveikatos priežiūros specialistų priešinimąsi, kaip vieną iš svarbiausių problemų, nurodo dauguma įstaigų, teikiančių sveikatos priežiūros paslaugas, todèl dabar, jau turint darbo patirties su e. sveikatos sistema, labai svarbu ir aktualu išsiaiškinti galimus esminius veiksnius, kurie sunkina e. sveikatos plètrą sveikatos apsaugos sistemoje. Labai svarbu tirti savanaudiškus, iracionalius motyvus, kurie skatina darbuotojus priešintis bet kokiai, net ir aiškiausiai naudingai inovacijai [11]. E. sveikatos sistemos diegimo ir plètros sėkmè priklauso nuo sveikatos priežiūros darbuotojų požiūrio ị ją.

Tyrimo tikslas - išanalizuoti stacionarinès asmens sveikatos priežiūros ịstaigos (ASPİ) specialistų požiūrị ị e. sveikatos paslaugų diegimo ir pletros problemas ir nustatyti priešinimąsi didinančius veiksnius.

\section{Tyrimo objektas ir metodai}

Tyrimas atliktas $2021 \mathrm{~m}$. Klaipèdos mieste. Tyrimas kiekybinis - anketinė apklausa raštu. Anketa sudaryta atsižvelgiant ị kitų mokslininkų atliktus tyrimus, kurie nagrinèjo e. sveikatos paslaugas. Tyrime dalyvavo stacionarinès ASPI administratoriai, gydytojai ir slaugos personalas. Tiriamujų imtis buvo apskaičiuota statistinio paketo Epi Info 7 imties skaičiavimo programa StatCalc. Tyrimo imtis sudaryta remiantis 95,0 proc. pasikliovimo lygmeniu ir 5 proc. paklaidos tikimybe (p). Statistiniai duomenys apdoroti naudojant IBM SPSS 23.0 (Statistical Package for the Social Sciences) programini paketą. Respondentų atsakymų pasiskirstymas išreikštas absoliučiaisiais skaičiais ir procentine išraiška, skirtumai nustatyti naudojant $\chi^{2}$ testą. Rezultatai laikyti statistiškai reikšmingi, kai $\mathrm{p}<\alpha=0,05$. Koreliacija tarp ranginių kintamujų vertinta Spearman koreliacijos koeficientu (r). Dviejų imčių ranginių kintamujų vidurkiams lyginti naudotas Mann Whitney U testas.

\section{Tyrimo rezultatai}

Bendra tiriamuju charakteristika. Tyrime dalyvavo 255 respondentai. Didžiąą dalị apklaustụjų sudarè moterys (76,5\%), likusią dali (23,5\%) - vyrai. Apklausos dalyviai, apjungiant amžiaus kategorijas, buvo suskirstyti i 2 grupes: pirma grupe - 18-50 metų, antra grupé 51 metai ir daugiau. Atskirai didžiausią dalị pagal amžiaus kategorijas sudarè respondentai nuo 51 iki 60 metų (28\%). Respondentai pagal išsilavinimą buvo suskirstyti ị dvi grupes: 1 - igiję aukštajị universitetinị išsilavinimą (68,2\%), 2 - aukštesniji neuniversitetinị išsilavinimą (31,8\%). Pagal užimamas pareigas respondentai buvo suskirstyti i 3 grupes: 1 - vadovai $(19,6 \%), 2$ - gydytojai (36,1\%), 3 - slaugytojai (44,3\%).

Problemos, su kuriomis susiduriama, naudojantis e. sveikata. Analizuojant tyrimo duomenis nustatyta, kad pagrindinè problema - e. sveikatos sistemos sutrikimai ir gedimai, kurie ilgina paciento apžiūros laiką ir eiles (1 pav.).

Apklausos duomenys parodè, kad ịvardintos problemos statistiškai reikšmingai priklauso nuo amžiaus $(\mathrm{p}<\alpha=0,05)$. Respondentai, priklausantys antrai amžiaus grupei, statistiškai reikšmingai dažniau nurodė, kad e. sveikatos sistemos sutrikimai ilgina paciento apžiūros laiką ir eiles $(65,7 \%) \mathrm{p}<0,05)$, lyginant su pirmos amžiaus grupès respondentais $(62,7 \%)$.

Reikšmingi skirtumai nustatyti ir grupèse pagal išsilavinimą: dauguma respondentų, turinčių aukštaji universitetinị išsilavinimą, nurodè, kad e.

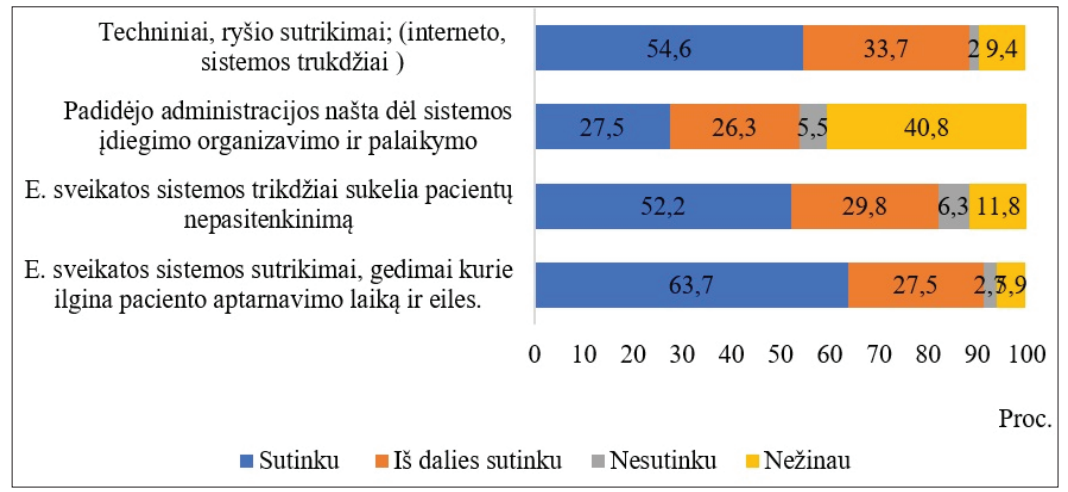

1 pav. Tiriamųų naudojimosi e. sveikatos sistema problemos, proc.

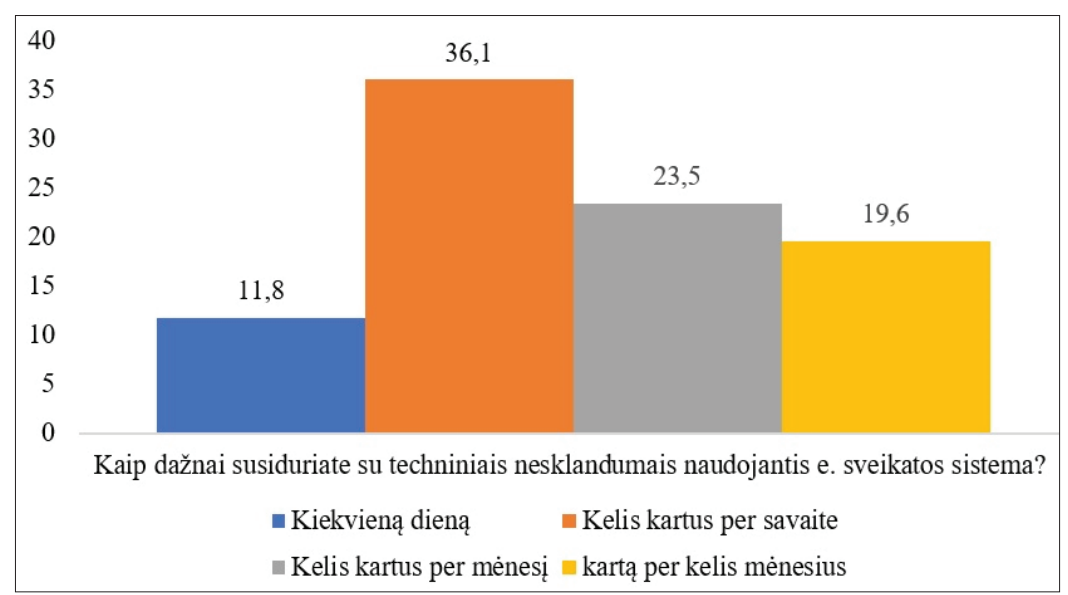

2 pav. Respondentų patiriamų e. sveikatos techninių nesklandumų dažnis, proc. 
sveikatos sutrikimai ilgina paciento apžiūros laiką ir eiles $(71,8 \%)(\mathrm{p}<\alpha=0,05), \mathrm{kad}$ dažniau susiduria su techniniais ar internetinio ryšio sutrikimais $(59,8 \%)(\mathrm{p}<\alpha=0,05)$. Mažiau nei pusè respondentų, turinčių aukštajį universitetinį išsilavinimą, nurodè, kad padidejo administracijos našta dèl sistemos įdiegimo, organizavimo ir palaikymo $(31,0 \%$ visų apklaustujų) $(\mathrm{p}<\alpha=0,05)$, lyginant su respondentais, kurie turèjo aukštesnijj neuniversitetinị išsilavinimą $(19,8 \%)$.

Nustatyti reikšmingi skirtumai priklausomai ir nuo užimamų pareigų. Didžioji

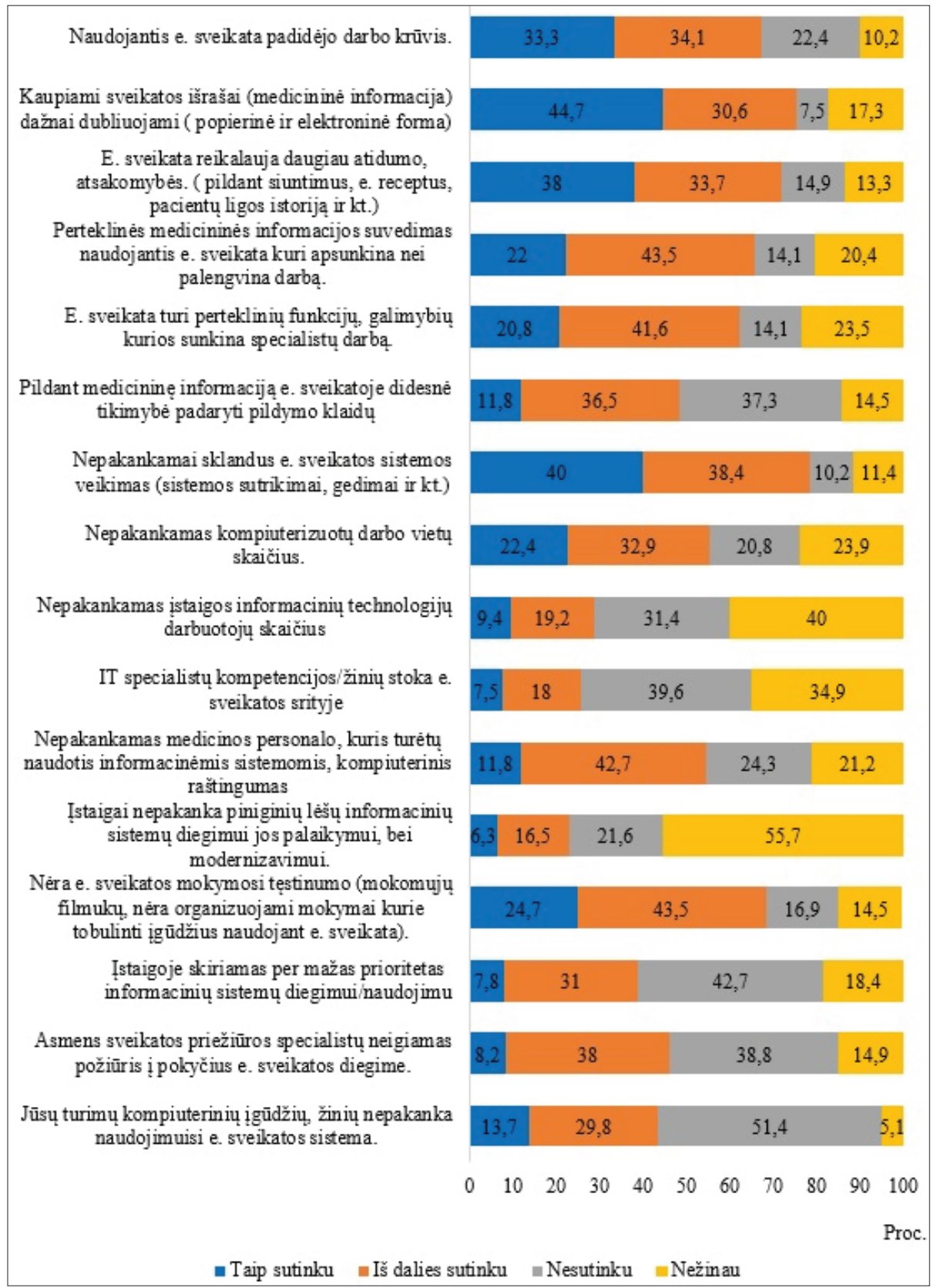

3 pav. Respondentų nuomonė apie veiksnius, didinančius priešinimąsi e. sveikatos sistemos diegimui ir plètrai, proc. dalis gydytojų dažniau sutiko su teiginiu, kad. e. sveikatos sistemos sutrikimai turi įtakos paciento apžiūros laikui ir eilei $(78,3 \%)$, lyginant su vadovais $(60,0 \%)$ ir slaugytojais $(54,0 \%)(\mathrm{p}<\alpha=0,05)$. Daugiau kaip pusè gydytojų nurodè, kad naudodamiesi e. sveikatos sistema, dažniau susiduria su techniniais ir ryšio sutrikimais $(66,3 \%)$, lyginant su vadovais $(54,0 \%)$ ir slaugytojais $(46,0 \%)$ $(\mathrm{p}<\alpha=0,05)$.

Išanalizavus atsakymus, kaip dažnai susiduriama su e. sveikatos sutrikimais, reikšmingų skirtumų nenustatyta. Daugiau nei trečdalis $(36,1 \%)$ respondentų sutrikimus pastebi kelis kartus per savaitę, kiti kelis kartus per dieną $(11,8 \%)$, kelis kartus per ménesi $(23,5 \%)$, arba kartą per keletą mėnesių (19,6\%) (2 pav.).

Priešinimąsi didinantys veiksniai. Siekiant ịvertinti respondentų nuomonę apie priešinimąsi didinančius veiksnius įdiegus ir plètojant e. sveikatą sveikatos priežiūros įstaigoje, buvo vertinamos jų kompiuterinès žinios, naudojimasis e. sveikatos sistema, IT specialistu kompetencija, kompiuterizuotu darbo vietų skaičius ir kiti teiginiai (3 pav.).

Atliktas tyrimas parode reikšmingus skirtumus tarp amžiaus grupių: respondentai, jaunesni nei 50 metų, statistiškai reikšmingai dažniau nesutiko su teiginiais $(\mathrm{p}<\alpha=0,05)(3 \mathrm{pav}$.), kad kaupiami sveikatos išrašai (medicininè informacija) dažnai dubliuojami su popierine ir elektronine forma $(10,5 \%)$ $(\mathrm{p}<\alpha=0,05) ; \mathrm{kad}$ e. sveikata reikalauja daugiau atidumo, atsakomybès pildant siuntimus, 
e. receptus, pacientų ligos istorijas ir kitą dokumentaciją $(18,3 \%)(\mathrm{p}<\alpha=0,05)$; kad pildant medicininę informaciją e. sveikatos platformoje didesné pildymo klaidų tikimybė $(43,8 \%)$. Respondentai, kurių amžius buvo 51 metai ir daugiau, statistiškai reikšmingai dažniau nesutiko su teiginiais, kad nepakankamas IT specialistų skaičius (33,3\%) $(\mathrm{p}<\alpha=0,05)$; kad IT specialistai stokoja kompetencijų (žinių) e. sveikatos srityje $(40,2 \%)(\mathrm{p}<\alpha=0,05)$.

Analizuojant priešinimąsi didinančius veiksnius, nustatyti reikšmingi skirtumai tarp respondentų, turinčių aukštaji universitetinị išsilavinimą ir aukštesniji neuniversitetini išsilavinimą. Respondentai su aukštuoju universitetiniu išsilavinimu statistiškai reikšmingai dažniau nesutiko su teiginiais, kad jų turimų kompiuterinių igūdžių, žinių nepakanka naudotis e. sveikatos sistema $(58,0 \%$ visų apklaustų respondentų) $(\mathrm{p}<\alpha=0,05)$; kad dirbančių asmens sveikatos priežiūros specialistų neigiamas požiūris ị pokyčius, ịdiegus e. sveikatą $(44,3 \%)(\mathrm{p}<\alpha=0,05)$; kad istaigoje per žemas informacinių sistemų diegimo (naudojimo) prioritetas $(48,9 \%)$ $(\mathrm{p}<\alpha=0,05)$; kad darbovieteje nèra e. sveikatos mokymu tęstinumo $(17,2 \%)(\mathrm{p}<\alpha=0,05)$; kad įstaigai nepakanka piniginių lèšų informacinių sistemų diegimui, jos palaikymui bei modernizavimui $(27,6 \%)(p<\alpha=0,05)$; kad IT specialistams nepakanka e. sveikatos žinių (47,7\%) $(\mathrm{p}<\alpha=0,05)$; kad įstaigoje nepakankamas IT specialistų skaičius $(36,8 \%)$ $(\mathrm{p}<\alpha=0,05)$; kad pildant medicininę informaciją e. sveikatoje didesné pildymo klaidų tikimybè $(43,7 \%)(\mathrm{p}<\alpha=0,05)$; kad e. sveikata reikalauja daugiau atidumo, atsakomybès $(18,4 \%)(p<\alpha=0,05)$; kad kaupiami sveikatos išrašai dažnai dubliuojami $(9,2 \%)(\mathrm{p}<\alpha=0,05)$.

Vertinant duomenis pagal užimamas pareigas, nustatyti kiti reikšmingi skirtumai. Gydytojai statistiškai reikšmingai dažniau nesutiko su teiginiais, kad jų turimų kompiuterinių igūdžiu, žinių nepakanka naudojimuisi e. sveikatos sistema $(72,8 \%)(p<\alpha=0,05)$; kad asmens sveikatos priežiūros specialistų neigiamas požiūris ị pokyčius, ịdiegus e. sveikatą $(53,3 \%)(\mathrm{p}<\alpha=0,05)$; kad istaigoje per žemas prioritetas teikiamas informaciniu sistemų diegimui (naudojimui) $(58,70 \%)$, lyginant su vadovų $(46,0 \%)$ ir slaugytojų nuomone $(28,3 \%)(p<\alpha=0,05)$. Trečdalis apklaustų gydytojų statistiškai reikšmingai dažniau nesutiko su teiginiu, kad įstaigai nepakanka piniginių lèšų informacinių sistemų diegimui, jos palaikymui bei modernizavimui $(32,6 \%)$, lyginant su vadovais $(22,0 \%)$ ir slaugytojomis $(12,40 \%)(p<\alpha=0,05)$. Penktadalis gydytojų statistiškai reikšmingai dažniau nesutiko su teiginiu, kad nèra e. sveikatos mokymo tęstinumo $(21,70 \%)$, lyginant su vadovais $(18,0 \%)$ ir slaugytojomis $(12,40 \%)(p<\alpha=0,05)$. Gydytojai statistiškai reikšmingai dažniau nesutiko su teiginiu, kad e. sveikata reikalauja daugiau atidumo, atsakomybès pildant siuntimus, e. receptus, pacientų ligos istorijas ir kt. $(22,80 \%)$, lyginant su vadovais $(14,0 \%)$ ir slaugytojomis $(8,80 \%)(p<\alpha=0,05)$. Gydytojai statistiškai reikšmingai dažniau nesutiko su teiginiu, kad naudojantis e. sveikata padidejo darbo krūvis.

Vadovai statistiškai reikšmingai dažniau nesutiko su teiginiais, kad IT specialistams trūksta žinių e. sveikatos srityje $(52,0 \%)$, lyginant su gydytojais $(46,7 \%)$ ir slaugytojomis $(27,4 \%)(p<\alpha=0,05)$; kad gydymo įstaigoje yra nepakankamas informacinių technologijų darbuotojų skaičius $(44,0 \%)$, lyginant su gydytojais $(39,10 \%)$ ir slaugytojomis $(19,50 \%)$ $(\mathrm{p}<\alpha=0,05)$; kad pildant medicininę informaciją e. sveikatos sistemoje yra didesne tikimybe padaryti pildymo klaidų $(52,0 \%)$, lyginant su gydytojais $(46,70 \%)$ ir slaugytojomis $(27,40 \%)(\mathrm{p}<\alpha=0,05)$. Ir tik nedidelè dalis apklaustų vadovų statistiškai reikšmingai dažniau nesutiko su teiginiu, kad e. sveikata turi perteklinių funkcijų, galimybių, kurios sunkina specialistų darbą $(16,0 \%)$, lyginant su gydytojais $(12,0 \%)$ ir slaugytojomis $(15,0 \%)(\mathrm{p}<\alpha=0,05)$.

Tik nedidelè dalis slaugytojų statistiškai reikšmingai dažniau nesutiko su teiginiu, kad yra nepakankamas skaičius kompiuterizuotų darbo vietu $(26,50 \%)$, lyginant su vadovais $(18,0 \%)$ ir gydytojais $(15,20 \%)(\mathrm{p}<\alpha=0,05)$.

\section{Rezultatų aptarimas}

Svarbiausia e. sveikatos diegimo ir plètros problema respondentai dažniausiai ịvardijo e. sveikatos sistemos sutrikimus ir gedimus, dèl kurių ilgèja pacientų apžiūros laikas ir eilès $(63,7 \%)$. Tai statistiškai reikšmingai patvirtino jaunesni nei 50 metų specialistai, aukštaji universitetinị išsilavinimą turintys specialistai ir gydytojai $(\mathrm{p}<\alpha=0,05)$. Techninius ir ryšio sutrikimus kaip problemą statistiškai dažniau nurodė $(p<\alpha=0,05)$ aukštaji universitetinị išsilavinimą turintys specialistai ir gydytojai. Tokias ir panašias problemas ịvardijo ir kiti tyrejjai $[6,12]$.

Tyrimo metu išanalizavus respondentų nuomones, paaiškèjo, kad turintys aukštaji universitetinį išsilavinimą specialistai statistiškai reikšmingai dažniau $(\mathrm{p}<\alpha=0,05)$ nesutiko, kad jų turimų kompiuterinių žinių nepakanka naudotis e. sveikatos sistema. Mūsų tyrimo metu gauti rezultatai skyrèsi nuo kitų autorių $[11,13,14]$ tyrimų rezultatų. Pagrindinis skirtumas - šių autorių atliktuose tyrimuose buvo nustatyta kompiuterinio raštingumo žinių stoka, kitaip, nei mūsų tyrime, kuris parodè, kad tirtos įstaigos specialistų kompiuterinis raštingumas yra pakankamas.

Gydytojai ir ligoninès vadovai statistiškai reikšmingai $(p<\alpha=0,05)$ dažniau išskyrè šiuos požymius, kurie sukelia priešinimąsi e. sveikatos sistemos diegimui: įstaigoje per žemas informacinių sistemų diegimo, bei naudojimosi prioritetas, IT specialistų e. sveikatos sistemos žinių stoka. Šios ir panašios problemos išskirtos ir M. Lluch [15] atliktame tyrime. 
Analizuojant asmens sveikatos priežiūros specialistų požiūrị ị e. sveikatą nustatyta, kad įdiegus šią sistemą, tapo lengviau keistis tiesiogine informacija, susijusia su paciento sveikatos būkle, sumažèjo naudojamų popierinių dokumentų formų kiekis. Su tuo sutinka respondentai, turintys aukštaji universitetinį išsilavinimą, jaunesni nei 50 metų respondentai, gydytojai bei ịstaigos vadovai $(p<\alpha=0,05)$. Šiame tyrime gauti rezultatai yra panašūs į kitų autorių atliktų tyrimų rezultatus [16,17]. Tyrimai parode, kad dauguma gydytojų supranta ir teigiamai vertina plètojamos e. sveikatos sistemos naudą ir jos plačias galimybes.

\section{Išvados}

1. Priešinimasis e. sveikatai yra specifinè sąvoka, kuri nèra vienareikšmiškai apibūdinama ir turi savo specifiką, apimančią ivvairius aspektus.

2. Pagrindinè e. sveikatos diegimo ir plètros problema - e. sveikatos sistemos sutrikimai ir gedimai, ilginantys pacientų apžiūros laiką ir eiles.

3. Tyrimo metu nustatyti veiksniai, didinantys priešinimąsi sèkmingam e. sveikatos sistemos diegimui ir plètrai: nepakankamai sklandus e. sveikatos sistemos veikimas, e. sveikatos sistema reikalauja daugiau atidumo ir atsakomybès, nepakankamas skaičius personalo, gebančio naudotis informacinèmis sistemomis, didelè medicininių dokumentų pildymo e. sveikatos sistemoje klaidų tikimybè, kaupiami sveikatos ịrašai dubliuojami, naudojantis e. sveikata padidèjo darbo krūvis.

4. Norint gauti tikslesnius duomenis apie priešinimosi mažinimo veiksnius ir priemones e. sveikatos diegimui ir plètrai, reikalingi didesnès apimties tyrimai.

\section{Literatūra}

1. Mogharbel A, Dowding D, Ainsworth J. Physicians' Use of the Computerized Physician Order Entry System for Medication Prescribing: Systematic Review. JMIR Med Inform 2021;9(3):e22923.

https://doi.org/10.2196/22923

2. Bokolo AJ. Application of telemedicine and eHealth technology for clinical services in response to COVID 19 pandemic. Health Technology 2021;11(2):359-366.

https://doi.org/10.1007/s12553-020-00516-4

3. Ahlan AR, Ahmad BI. User Acceptance of Health Information Technology (Hit) in Developing Countries: a Conceptual Model. Procedia Technology 2014;16:1287-1296.

https://doi.org/10.1016/j.protcy.2014.10.145

4. Ngafeeson M. Understanding User Resistance to Information Technology in Healthcare: The Nature and Role of Perceived Threats. Transactions of the International Conference on Health Information Technology Advancement 2015;3(1):37-49.
5. Mareš J. Resistance of health personnel to changes in healthcare. Elsevier 2018;(20)3.

https://doi.org/10.1016/j.kontakt.2018.04.002

6. Sweis R, Isa A, Azzeh H, Shtyh B, Musa E, AlBtoush R. Nurses' Resistance to the Adoption of Information Technology in Jordanian Hospitals. Life Science Journal 2014;11(4s):8-18.

7. Hayward K, Schuilenburg M. To resist = to create? Some thoughts on the concept of resistance in cultural criminology. Tijdschrift Over Cultuur Criminaliteit 2014;4(1):22-36. https://doi.org/10.5553/TCC/221195072013003003003

8. Ryan E. Bioethics. Resistance in Health and Healthcare 2021;35(5):480-486. https://doi.org/10.1111/bioe.12862

9. Jasulaitis A., Plenta J., Justickis V., Plentienė J. Sveikatos apsaugos įstaigos darbuotojų pasipriešinimo inovacijoms motyvai. Sveikatos politika ir valdymas, 2012; 1(4):272-295. https:// repository.mruni.eu/bitstream/handle/007/12862/291-458-1 SM.pdf? sequence $=1 \&$ is Allowed $=y$

10. Lietuvos Respublikos sveikatos apsaugos ministerija. Analizès, kaip diegiama nacionalinè e. sveikatos sistema, galutinè ataskaita 2011. http://www.esparama.lt/es_parama_pletra/failai/ ESFproduktai/2012_analize_kaip_diegiama_nacionaline_e_ sveikatos_sistema.pdf.

11. Jankauskienė D., Mikulskienė B., Pitrènaitė-Žilènienė B., Skaržauskienė A., Štitilis D., Rotomskienė R., Štaras K., Mačiulienė M., Pukinaitė V., Stokaitė V., Tamošiūnaitė R. E. sveikatos plètros integruotos transformacijos: suinteresuotujų pusių tinklo perspektyva. Monografija. Vilnius: Mykolo Romerio universitetas, 2015.

12. Lietuvos Respublikos valstybès kontrolès valstybinio audito ataskaita Elektroninès sveikatos sistemos kūrimas. 2017; VA2017-P-900-3-12. https://www.vkontrole.lt/.

13. Štaras K., Mačiulienė M., Stokaitė V. Informacinių ir komunikacinių technologijų ịtaka sveikatos priežiūros paslaugų teikimui. Sveikatos politika ir valdymas, 2013;1(5):148-166. https://doi.org/10.13165/SPV-13-1-5-10

14. Zayyad M, Toycan M. Factors affecting sustainable adoption of e-health technology in developing countries: an exploratory survey of Nigerian hospitals from the perspective of healthcare professionals. PeerJ 2018;6(6):e4436.

https://doi.org/10.7717/peerj.4436

15. Lluch M. Healthcare professionals organisational barriers to health information technologies - a literature review. International Journal of Medical Informatics 2011;80(12):849-862. https://doi.org/10.1016/j.ijmedinf.2011.09.005

16. Jankauskienė D., Jakubčionytė A. Sveikatos priežiūros įstaigų dalyvavimas e. sveikatos sistemoje. Sveikatos politika ir valdymas, 2014;1(6):80-98.

https://doi.org/10.13165/SPV-14-1-6-06

17. Dünnebeil S, Sunyaev A, Blohm I, Leimeister JM, Krcmar H. Determinants of physicians' technology acceptance for e-health in ambulatory care. International Journal of Medical 
Informatics 2012;81(11):746-760.

https://doi.org/10.1016/j.ijmedinf.2012.02.002

\section{THE RESISTANCE OF MEDICAL STAFF FOR THE DEVELOPMENT OF E. HEALTH SYSTEM SERVICES \\ G. Virketis, G. Kazlauskè}

Keywords: e. health, e. health services, resistance.

Summary

Scientific literature shows that medical staff opposes development of e. Health system, although e. Health system is applied and improved for several years. To this day the concept of resistance of medical staff for e. Health system does not have consensus.

The aim of this work - to analyse stationary personal healthcare institution specialists' approach to problems and resistance increasing factors for installing and expanding services of e. Health system.

Methods - Quantitative research - questionnaire in written form. Questionnaire was concluded taking into account researches that has been carried out by other scientists. 255 respondents attended in this research. Statistical data was processed using IBM SPSS 23.0 (Statistical Package for the Social Sciences) program package.

Results. In summary we can say that the biggest part of respondents has enough computer knowledge to use e. Health system. Our researched institution gives less priority for installment of information technology systems than it should be given, although IT specialists that work in that institution has enough competence to do it. Filling medical information in e. Health system occurs probability to make some human filling errors. Interviewed respondents says that the work of e. Health system is not fluent enough. Working with this system requires more concentration and responsibility. The work load of stationary personal healthcare institution specialists that are working with e. Health system has increased.

Conclusions. The main problem of installing and development of e. Health system is its malfunctions and failures that makes inspection time of a patient and queues longer. The results shown that the main reasons of resistance for installing and development of e. Health system are: e. Health system is not working fluent enough; working with this system requires more concentration and responsibility; the number of personnel that is capable of using information systems is too low; filling medical information in e. Health system occurs probability to make some human filling errors; accumulated health records are duplicated; using e. Health system increases the work load. However, we can say that the most of physicians understands and evaluates positively the benefits that e. Health system provides and its wide opportunities.

Correspondence to: virketis@kul.lt

Gauta 2021-10-13 